Tersedia online di: http://ejournal-balitbang.kkp.go.id/index.php/JP
e-mail:jurnalpari@gmail.com
JURNAL PARI
volume 6 Nomor 1 Juli 2020
p-ISSN: 2502-0730
e-ISSN : 2549-0133

\title{
PERAN HUMAS DALAM MEMBANGUN EKSISTENSI POLITEKNIK KELAUTAN DAN PERIKANAN PANGANDARAN
}

\author{
Papa Samrotul Puadah
}

\author{
Unit Teknologi Informasi dan Inovasi Politeknik Kelautan dan Perikanan Pangandaran \\ dlterima tanggal : 7 April 2020 Diterima setelah perbaikan : 13 Juli 2020 \\ Disetujui terbit tanggal : 21 Juli 2020
}

\begin{abstract}
ABSTRAK
Humas merupakan ujung tombak dalam menyampaikan informasi kegiatan yang dilaksanakan, dan program kerja pada suatu institusi. Selain itu, humas sebagai corong atau sumber informasi, yang dituntut kemampuannya dalam menghadapi tantangan dan perubahan zaman yang sangat cepat terutama menghadapi perkembangan teknologi, informasi dan komunikasi. Humas memiliki peranan penting dalam menyampaikan informasi pada khalayak umum. Selain itu humas di tuntut untuk menguasai teknologi informasi dan komunikasi, termasuk di dalamnya media sosial sehingga dapat mengetahui informasi yang sedang ramai dibicarakan. Peran kehumasan dalam membangun eksistensi Politeknik Kelautan dan Perikanan Pangandaran diharapkan dapat memenuhi kebutuhan informasi dan tututan masyarakat. Humas sebagai perpanjangan tangan dari sebuah institusi diharapkan dapat memberikan kontribusi terhadap eksistensinya Politeknik Kelautan dan Perikanan Pangandaran.
\end{abstract}

Kata Kunci: Humas; Eksistensi; Media Sosial; Politeknik Kelautan dan Periakanan Pangandaran.

\begin{abstract}
ABSTARCT
Public Relations is the spearhead in conveying information on activities carried out, and work programs at an instituation. In addition, public relations as a mouthpiece or source of information, wich is demanded for its ability to face the challengs and changing time very quickly, especially, facing the development of technology, information and communication. Public Relation has an important role in conveying information to the general public. In addition, public relations are demaded to master information and communication technology, including social media do they can find out information that is being talked about. The role of public reations in building the existence of Pangandaran Marine and Fisheries polytechnic is expected to meet the needs of information and public demands. Public Relations ans an extension of an instituation are expected to contribute to the existence of of Pangandaran Marine and Fisheries polytechnic.
\end{abstract}

Keywords: Public Relation; Existence; Social Media; Pangandaran Marine and Fisheries Polytechnic. 


\section{PENDAHULUAN}

Politeknik KP Pangandaran merupakan Perguruan Tinggi di lingkungan Kementerian Kelautan dan Perikanan, yang bertempat di Kabupaten Pangandaran, Provinsi Jawa Barat. Politeknik Kelautan dan Perikanan Pangandaran yang disingkat Politeknik KP Pangandaran, adalah perguruan tinggi yang menyelenggarakan pendidikan vokasi di bidang kelautan dan perikanan. Pendidikan Vokasi adalah pendidikan tinggi yang menyiapkan Taruna untuk memiliki pekerjaan dengan keahlian terapan ilmu di bidang kelautan dan perikanan. Politeknik Kelautan dan Perikanan Pangandaran berkomitmen menghasilkan lulusan yang berkualitas, berkarakter dan menerapkan Pilar 4C (Competence, Consistency, Commitment, and Conscience). Dalam upaya mewujudkan eksistensi Politeknik Kelautan dan Perikanan Pangandaran maka deperlukan peran humas dalam hal ini dilaksanakan pada Unit teknologi Informasi dan Inovasi.

Peran Humas di era kemajuan teknonogi dan informasi sekarang bukan lagi sebagai penyampai informasi, melainkan menjadi salah satu unsur strategis dalam mendukung kesuksesan pelaksanaan progam pemerintah. Terutama menciptakan reputasi kinerja pemerintahan yang baik (good governance) di masyarakat.

Humas memiliki peran sangat strategis pada institusi. Menjadi unsur kedua setelah pimpinan dalam hal ini direktur yang fungsinya berbicara - keluar dan kedalam - atau sering disebut two way communication (komunikasi dua arah). Karena itu, Humas selayaknya mengetahui segala hal dan diberi bekal kompetensi yang disesuaikan dengan Standar Operasional Prosedur (SOP).

Humas harus mampu menjalin kemitraan dengan berbagai media (media relation) dalam mempublikasikan kegiatan, baik melalui media cetak maupun media elektronik. Sebab, kesuksesan penyelenggaraan kegiatan dapat terlihat dari seberapa besar peran Humas dan respon masyarakat. Artinya, setiap informasi kegiatan harus disampaikan secara cepat dan tepat sasaran. Dalam hal ini jika kalau humas dapat melaksanakan peran dengan baik, maka citra institusi akan positif di masyarakat. Eksistensi Humas pun sangat mendukung aktivitas organisasi, dan karena itu Humas miliki peranan penting dalam eksistesni sebuah institusi. Maka dari itu pelaksanaannya harus dapat dukungan berbagai pihak.
Peranan Humas pada sebuah institusi baik itu pemerintah mapupun swasta sangat penting dalam membangun citra positif bangsa dan Negara. Humas selalu dituntut kemampuannya dalam menghadapi tantangan dan perubahan lingkungan yang sangat cepat. Dan di era keterbukaan sekarang ini Humas mempunyai peran ynag penting dan strategis. Humas merupakan penunjang tercapainya tujuan yang ditetapkan oleh suatu manajemen organisasi.

Sasaran Humas adalah publik internal dan eksternal, di mana secara operasional Humas bertugas membina hubungan harmonis antara organisasi dengan publiknya dan mencegah timbulnya rintangan psikologis yang mungkin terjadi di antara keduanya. Secara defenitif, Humas adalah suatu fungsi manajemen yang bertujuan menjembatani antara organisasi dan stakeholder baik di luar maupun di dalam.

Humas harus mengetahui segala kebijakan dari tujuan organisasi. Jadi Humas sebagai juru bicara harus mengetahui segala kebijakan publik yang diambil itu dapat diimplementasikan dengan baik, dan sangat membutuhkan dukungan publik. Bagaimana mungkin publik mau atau mendukung, ketika tidak mampu menterjemahkan dan mengetahui maksud serta tujuan kebijakan yang dipublikasikan. Untuk itu sangat diperlukan penyampai pesan yang baik serta mudah diterjemahkan maksud dan tujuannya oleh publik dan peranan humas yang harus mampu memfasilitasinya segalanya. Jadi salah satu peran Humas adalah membina hubungan yang harmonis dengan masyarakat dan membina reputasi instansi dalam pandangan masyarakat, guna memperoleh pengertian, kepercayaan dan dukungan dari masyarakat.

Humas dituntut berperan dan berfungsi secara strategis dan profesional sehingga seorang humas haruslah memiliki kualifikasi yang memadai. Ada tiga tugas humas dalam organisasi/lembaga yang berhubungan erat dengan tujuan dan fungsi humas. Ketiga tugas tersebut adalah sebagai berikut:

1. Menginterpretasikan, menganalisis dan mengevaluasi kecenderungan perilaku publik, kemudian direkomendasikan kepada manajemen untuk merumuskan kebijakan organisasi/lembaga.

2. Mempertemukan kepentingan organisasillembaga dengan kepentingan publik. Kepentingan organisasi/lembaga dapat jadi jauh berbeda dengan kepentinga publik dan sebaliknya, namun 
dapat juga kepentingan ini jauh berbeda bahkan dapat juga kepentingannya sama.

3. Mengevaluasi program-program organisasi/ lembaga, khususnya yang berkaitan dengan publik. Tugas mengevaluasi program manajemen ini mensyaratkan kedudukan dan wewenang humas yang tinngi dan luas. Karena tugas ini dapat berarti humas memiliki wawanang untuk memberi nasehat apakah suatu program sebaiknya di teruskan ataukah ditunda/dihentikah.

Kegiatan-kegiatan Humas pada dasarnya diarahkan:

- Pertama, memberikan informasi kepada khalayak umum tentang tugas pokok, fungsi, aktivitas dan kebijaksanaan-kebijaksanaan institusi/lembaga.

- Kedua, menangkap aspirasi masyarakat dan menyampaikan kepada Institusi/lembaga atau satuan kerja di jajaran Politeknik Kelautan dan Perikanan Pangandaran.

- Ketiga, meuwujudkan integrasi, keserasian dan keselarasan antara kepentingan institusi/lembaga dan kepentingan masyarakat.

- Keempat, mendorong dan menegakkan peran aktif masyarakat dalam memahami betapa pentingnya peran pendidikan dalam mewujudkan Indonesia Maju dan,

- Kelima, meningkatkan dan mempertahankan nama baik Institusi di jajaran Politeknik Kelautan dan Perikanan Pangandaran.

Humas merupakan singkatan dari Hubungan Masyarakat atau dalam bahasa Inggris disebut dengan Public Relation (PR) yang bertanggungjawab dalam membangun dan mempertahanan reputasi, citra, dan komunikasi yang baik dan bermanfaat antara organisasi dan publik. Dalam dunia bisnis, fungsi humas kerap dikaitkan dengan marketing, padahal sangat berbeda. Sebagai profesi, bidang Humas membantu mendidik, memberikan infomasi, membangkitkan ketertarikan masyarakat, merencanakan strategi untuk meraih simpati hingga membuat masyarakat mengerti dalam situasi tertentu.

Pada institusi Politeknik Kelautan dan Perikanan Pagandaran,devenisi Humas memiliki peran sebagai juru bicara yakni dengan mempublikasikan kegiatan yang dilaksanakan meliputi kegiatan Pengajaran dan Perkuliahan, Praktek Teaching Factory, Praktek Mata Kuliah, Praktek Kerja Lapang, Kewirausahaan, Sertifikasi Peserta Didik, Pendidikan Karakter, Kegiatan Ketarunaan, Kegiatan Ektra Kurikuler dan Kerohanian, Penelitian Terapan dosen dan
Pengabdian Masyarakat. Serta mendokumentasikan segala bentuk kegiatan yang berkaitan dengan Eksistensi Institusi Politeknik Kelutan dan Perikanan Pangandaran secara umum. Tak hanya itu saja, Humas juga berperan sebagai mitra pencitraan good goverment dengan media massa sehingga jalinan kerjasama antara institusi/lembaga yang diwakili oleh Humas dengan media massa berjalan dengan baik dalam rangka memberikan informasi kepada khalayak umum.

Memasuki era globalisasi dan informasi dalam kehidupan modern begitu penting, artinya mengatur bagaimana kita berhubungan antara orang yang satu dengan orang lainnya. Begitu juga halnya dalam hal konteks organisasi maupun perusahaan. Humas merupakan salah satu hal yang bisa mengakomodir semua kebutuhan suatu relasidan berkomunikasi dengan orang lain. Humas yang baik wajib dimiliki oleh semua anggota publik pada umumnya terutama masyarakat organisasi pada khususnya membantu untuk kelancaran hubungan kerja yang baik pada organisasi tersebut (Farouk, 2009: 68)

\section{Peranan Pelaksana Humas}

Peranan humas dapat digolongkan menjadi 4 (empat) peran, diantanya yaitu:

\section{Expert Preciber Communication}

Pelaksana humas atau pranata humas dianggap sebagai seorang ahli. Dia memiliki hubungan yang sangat erak kaitannya dengan pimpinan dalam menyampaikan informasi mengenai kebijakan pimpinan atau institusi.

\section{Problem Solving Process Facilitator}

Pelaksana humas atau pranata humas berperan sebagai fasilitator dalam proses pemecahan masalah. Pada peranan ini pelaksa humas melibatkan diri atau dilibatkan dalam setiap kegiatan, bahkan dalam penanganan masalah menyangkut institusi.

\section{Communication Facilitator}

Pelaksana humas berperan sebagai fasilitator komunikasi antara institusi/lembaga dengan publik. Baik dengan publik exsternal maupun internal. Istilah yang paling umum adalah sebagai jembatan komunikasi antara publik dengan institusi/lembaga. Sebagai media atau penengah bila terjadi kesalahan pahaman berkomunikasi atau miss communication. 


\section{Tehnician Comunication}

Pelaksana humas dianggap sebagai pelaksana teknis komunikasi. Dia melayani layanan di bidang teknis, sementara kebijakan dan keputusan teknik komunikasi mana yang akan digunakan bukan merupakan keputusan petugas humas, melainkan keputusan manajemen dan petugas humas yang melaksanakan.

\section{Peran Humas Dalam Membangun Eksistensi Institusi/Lembaga}

Kemajuan teknologi memunculkan adanya media baru. Media baru adalah media yang memanfaatkan jaringan internet dalam aktivitasnya yang menitikberatkan pada kecepatan informasi bagi pengunggahnya dibanding dengan media konvensional seperti surat kabar ataupun televisi. Media baru ini sering disebut dengan media online. Adanya media baru dapat digunakan oleh pekerja humas (Public Relations Officer) untuk melaksanakan fungsinya dalam berkomunikasi, memberikan informasi pada khalayak umum.

Dalam membangun eksistensi instusi/lembaga dalam hal ini Politeknik Kelautan dan Perikanan Pangandaran menggunakan social media. Mulai dari pengelolaan website, instagram, facebook, twitter dan youtube. Di era 4.0 ini kompetisi yang semakin ketat maka membangun eksistensi dan reputasi merupakan tuntutan yang sangat mendesak dan wajib. Eksistensi humas pada suatu institusi/lembaga tercermin pada fungsi dan peran yang diembannya. Eksistensi humas pada setiap institusi/lembaga akan senantiasa berbeda tergantung dari besar atau kecilnya lembaga tersebut, akan tetapi untuk melihat eksistensi humas cukup pada fungsi dan difungsikannya humas pada institusi/lembaga tersebut.

\section{Peran Media Sosial Dalam Membangun Eksistensi Politeknik Kelautan dan Perikanan Pangandaran}

Zaman semakin maju dan tekologi semakin canggih. Jika dulu komunikasi masih terbatas, kini komunikasi bisa dilakukan tanpa terbatas ruang dan sekat. Adanya media sosial berbasis internet membuat informasi semakin mudah untuk disampaikan kepada publik.

Banyaknya platform media sosial berbasis daring ini sekaligus mendukung keterbukaan informasi yang digalakkan oleh pemerintah. Keterbukaan informasi ini ditandai dengan lahirnya UU No 14 Tahun 2008 tentang Keterbukaan Informasi Publik.
Dalam upaya menyampaikan informasi kegiatan yang dilaksanakan di Politeknik Kelautan dan Perikanan Pangandaran, dan sebagai upaya pemenuhan keterbukaan informasi kepada publik. Peranan media sosial sangat penting dalam membangun eksistensi Politeknik Kelautan dan Perikanan Pangandaran, dengan tujuan sebagai berikut:

- Menyampaiakn informasi dengan muatan positif

- Meningkatkan peran aktif humas dalam menyampaikan informasi yang transparan, efektif dan efisien, akuntabel serta dapat dipertanggungjawabkan

- Meningkatkan pengelolaan dan pelayanan informasi di lingkungan Politeknik Kelautan dan Perikanan Pangandaran

- Menghasilkan layanan informasi yang berkualitas dan mencerdaskan publik.

Saat ini institusi/lembaga pemerintah ataupun swasta memiliki website dan media sosial untuk menyampaikan kebijakan dan capaian-capaiannya. Maka peran media sosial menjadi sangat sentral dalam memberikan informasi-informasi yang bermanfaat kepada publik. Keberadaan media sosial mendorong Politeknik Kelautan dan Perikanan Pangandaran lebih efektif dalam menyampaikan informasi yang sedang berlangsung. Namun dalam upaya menyampaikan informasi ada tantangannya terutama menyajikan informasi dalam bahasa yang mudah dicerna dan bisa menggiring dukungan masyarakat. Meskipun demikian peranan media sosial sangat strategis dalam penyebaran informasi yang dilakukan oleh humas.

\section{Strategi Humas Dalam Mengelola Media Sosial}

Memahami dengan jelas tentang bagaimana kinerja dan tugas dari humas tentunya dalam suatu lembaga Institusi Pendidikan yang sedang di jalankan setidaknya punya pegangan untuk bagaimana dan mau dibawa kemana. Sebagai lembaga pendidikan Politeknik Kelautan dan Perikanan Pangandaran terus berusaha untuk maju dan berkembang harus mampu menciptakan image (citra) positif pada hati publik merupakan keharusan yang tidak boleh tidak harus dilaksanakan, sehingga publik mampu memberi keputusan untuk mendaftarkan para anak-anak mereka dan ikut serta dalam berpartisipasi aktif terhadap pengembangan lembaga pendidikan tersebut. Sehingga selain juga dengan melalui pengembangan kualitas juga membutuhkan kegiatan hubungan publik yang produktif berdasarkan visi misi yang jelas (Mundiri, 2016: 58). 


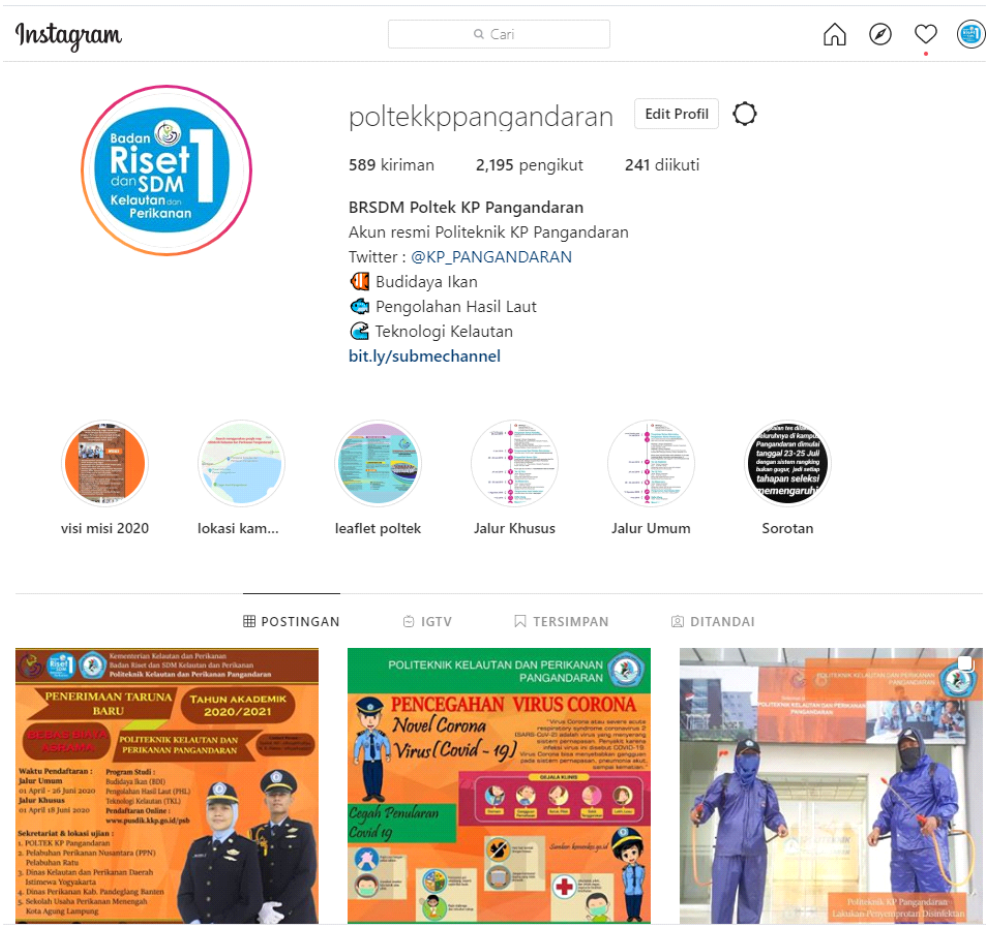

Gambar 1. Followers IG 2.195

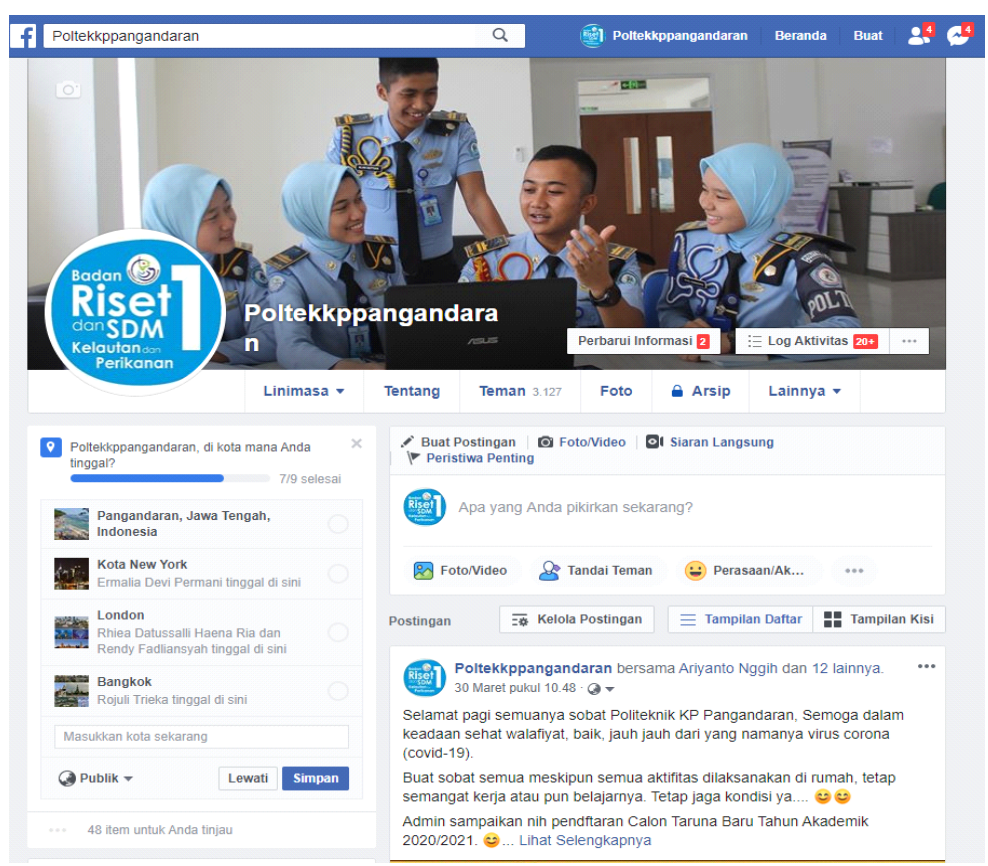

Gambar 2. Followers FB 3.127.195 


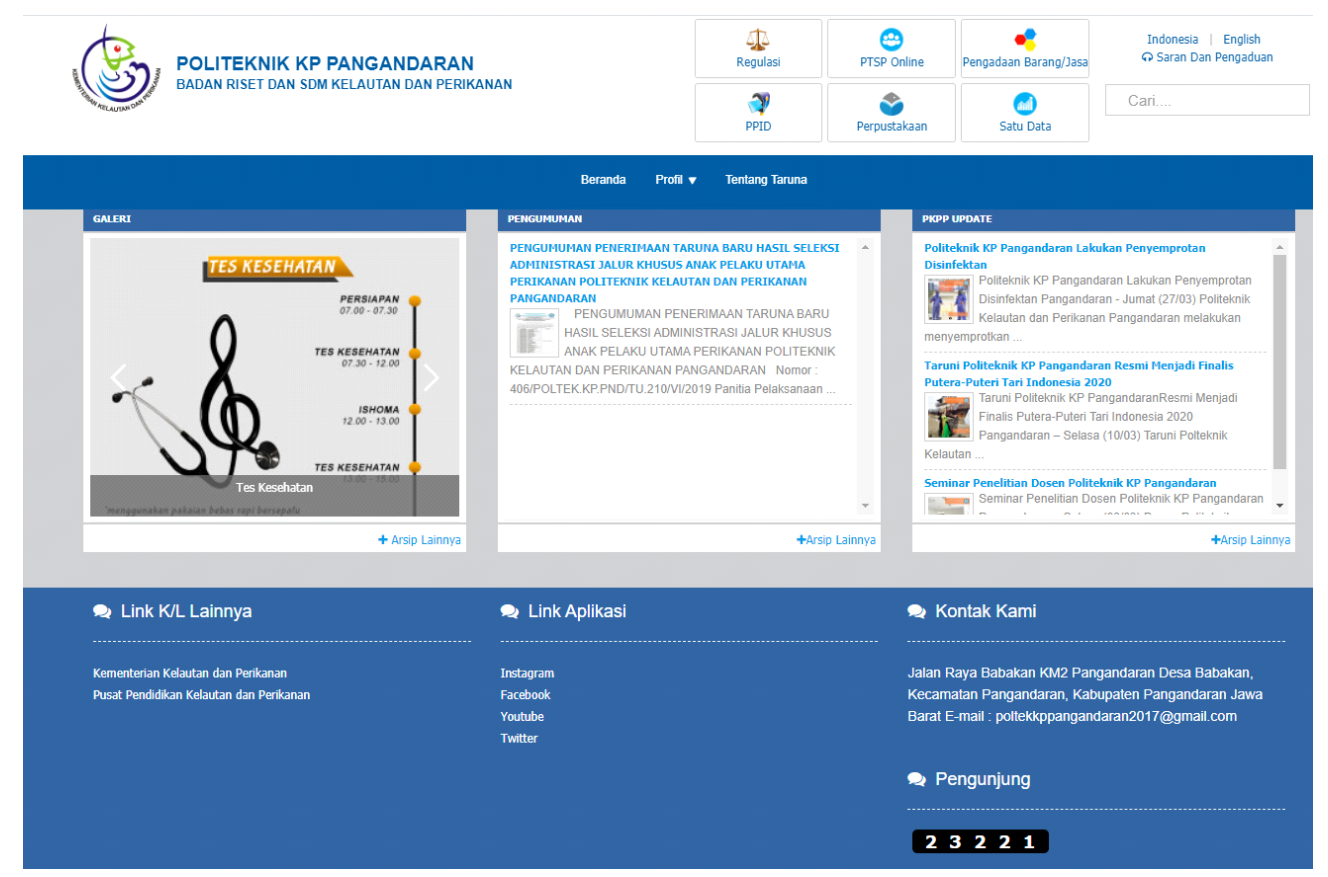

Gambar 3. Pengunjung pada laman website 23.321 pengunjung

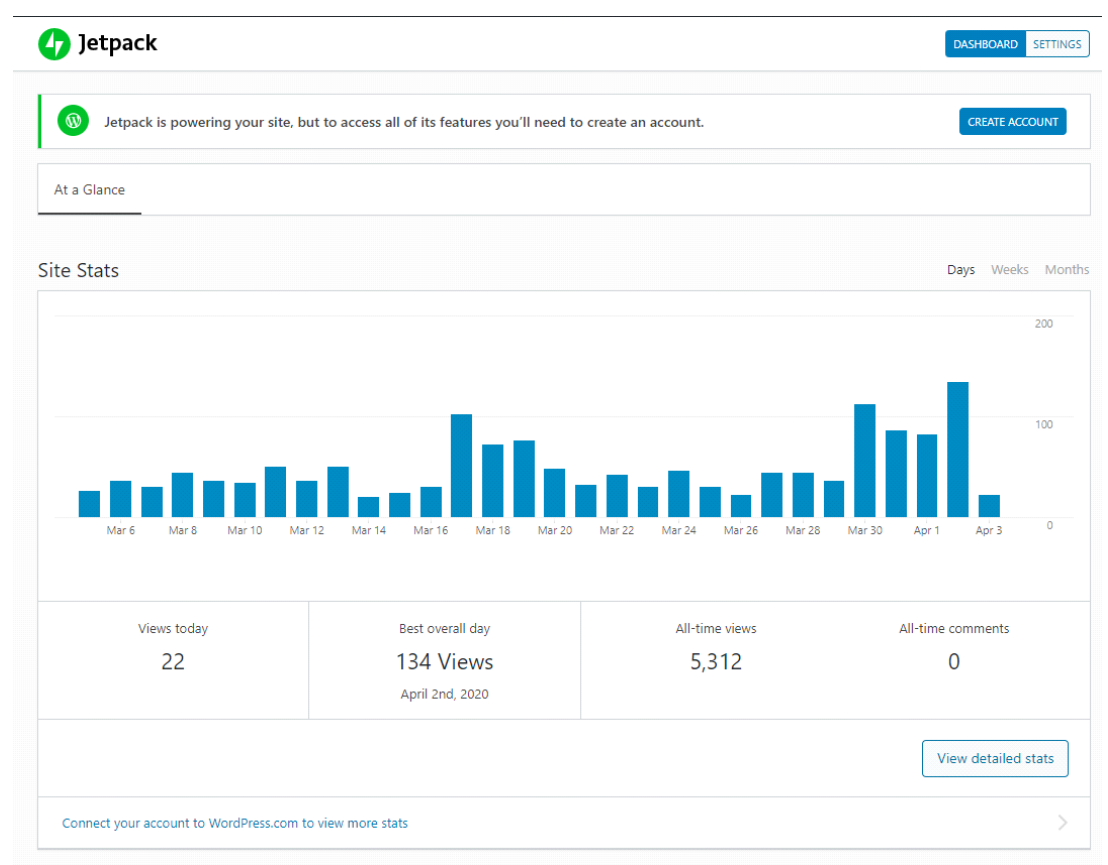

Gambar 4. Pengunjung pada laman website 5.312 pengunjung

Penggunaan media sosial di Politeknik Kelautan dan Perikanan Pangandaran menjadi hal yang penting bagi kelancaran arus informasi baik yang sifatnya informasi internal maupun eksternal. Yanti Herlanti (2004) menjelaskan bahwa Media sosial adalah media online yang memungkinkan bagi penggunauntuk berpartisipasi, berbagi dan menciptakan isi.
Pada dasarnya media sosial merupakan perkembangan mutakhir dari teknologi-teknologi web baru berbasis internet, yang memudahkan semua orang untuk berkomunikasi, berpartisipasi, saling berbagi dan membentuk sebuah jaringan secara online, sehingga dapat menyebarluaskan konten mereka sendiri. Post di Blog, Twit atau Video di 
Youtube dapat diproduksi dan dapat dilihat secara langsung oleh jutaan orang secara gratis. (Zarella, 2010). Media sosial adalah merupakan inovasi yang relatif terus berkembang, dan pemasaran media sosial merupakan industri yang relatif terus berkembang dinamis (Stelzner, 2016).

Penggunaan media sosial bisa merupakan sebuah respon positif ataupun negatif, akan tetapi dengan adanya respon tersebut baik yang positif atau negatif, maka dengan demikian dapat dipastikan bahwasanya segala bentuk penggunaan media sosial baik dalam rangka menyebarluaskan sebuah informasi atau lain hal memiliki daya tarik bagi publik. Politeknik Kelautan dan Perikanan Pangandaran melalui Unit Teknologi Informasi dan Inovasi terus berusaha memberikan informasi fositif dan merespon yang baik atas semua umpan balik yang diterimanya dari publik. Unit Teknologi Informasi dan Inovasi selalu mencoba memberikan repson yang aktif, komunikatif serta responsif atas semua umpan balik yang diterima, dengan demikian diharapkan adanya kepuasan dari para publik atas apa yang menjadi pertanyaan mereka.

Admin dari media sosial Politeknik Kelautan dan Perikanan Pangandaran yang ditangani langsung oleh Unit Teknologi Informasi dan Inovasi telah melakukan pengelolaan jejaring media sosial dengan sangat baik, yakni menggunakan bahasa dan tutur kata yang baik atau komunikatif, sehingga pesan yang disampaikan diterima baik oleh publik. Selain itu admin selalu berupaya untuk memberikan informasi yang dilakukan di Politeknik Kelautan dan Perikanan Pangandaran degan misi "one day one news". Hal tersebut dalam upaya membangun eksistensi Politeknik Kelautan dan Perikanan Pangandaran.

Melalui penggunaan media sosial Instagram, Facebook, Twitter, Youtube, dan website oleh Unit Teknologi Informasi dan Inovasi tiada lain dalam upaya menyampaikan informasi bahwa Politeknik Kelautan dan Perikanan Pangandaran menyelenggarakan pendidikan vokasi di bidang industri kelautan dan perikanan dengan pendekatan teaching factory, melaksanakan penelitian terapan, melaksanakan kegiatan pengabdian kepada masyarakat, membangun jiwa kewirausahaan di kalangan Civitas Akademika dan mengembangkan program kemitraan dan kerja sama dengan dunia usaha dan dunia industri, masyarakat, pemangku kepentingan di dalam dan luar negeri.

\section{HASIL DAN PEMBAHASAN}

Politeknik Kelautan dan Perikanan Pangandaran melalui Unit Teknologi Informasi dan Inovasi mencoba untuk menggunakan media sosial sebagai suatu wadah penyampaian dan juga penyebarluasan informasi kepada publik. Hal ini ditempuh sebagai jawaban atas perkembangan teknologi dan informasi pada era ini yang mengharuskan adanya penggunaan dan pengoptimalan penggunaan media sosial dalam kaitannya dengan keefektivitasannya dalam mengolah informasi. Penggunaan media sosial menjadi hal penting, karena dengan adanya penggunaan media sosial dalam mendukung kehidupan Politeknik Kelautan dan Perikanan Pangandaran mampu untuk dikenal oleh masyarakat yang lebih luas lagi terutama para pengguna media sosial, dengan demikan maka Politeknik Kelautan dan Perikanan Pangandaran akan mendapatkan perhatian yang cukup baik dari publik. Ini terbukti dalam satu tahun kebelakang Politeknik Kelautan dan Perikanan Pangandaran memiliki respon yang baik terlihat dari followers' dan viewers' media sosial.

Dalam menggunakan berbagai macam media sosial oleh Unit Teknologi Inormasi dan Inovasi Politeknik Kelautan dan Periakan Pangandaran maka didapatkan tanda informasi yang berbeda-beda tergantung media sosial yang digunakan. Admin media sosial Politekik Kelautan dan Perikanan Pangandaran melakukan kegiatan penanganan tanda informasi dengan responsif, artinya setiap ada tanda informasi yang didapatkan dari penggunaan media sosial baik berupa tanda informasi "komentar" atau "menyukai", maka akan mendapatkan respon balasan yang cukup responsive.

Adanya pengelolaan tanda informasi yang diberikan publik melalui media sosial yang dikelola oleh admin Unit Teknologi Informasi dan Inovasi, maka publik dan juga telah sama-sama melakukan kegiatan pengelolaan dan juga penyebarluasan informasi melalui media sosial sesuai dengan perkembangan zaman yang ada pada saat ini.

Dalam menggunakan media sosial yang berkaitan dengan penyebarluasan informasi dan juga pengelolaan informasi maka hal tersebut selaras dengan salah satu teori media sosial yakni Teori Kekayaan Media atau Media Richness Theory. Dalam teori kekayaan media dikatakan bahwasanya dalam penggunaan media sosial maka akan ditemukan berbagai macam perbedaan yang mencolok, yang artinya bahwa tidak semua media sosial memiliki kesamaan dalam kegiatan penggunaannya. Perbedaan yang bisa diketahui adalah dalam penggunaan media sosial akan didapatkan respon dan juga aktivitas yang berbeda satu sama lain, yang artinya penggunaan media sosial perlu dikembangkan lagi untuk mendapatkan respon yang 
beragam agar proses pengelolaan dan penyebarluasan informasi dapat dilakukan dengan efektif. Teori kekayaan media meliputi empat aspek pembahasan yakni; bagaimana dengan menggunakan media sosial Politenik Kelautan dan Perikanan mampu menangani tanda informasi, umpan balik, pengembangan fokus media sosia; keragaman bahasa (language variety) yang meliputi kata, angka, rumus, kode dan lambang lainnya; kemampuan media memfokuskan diri secara pribadi kepada penerima pesan atau kemapuan media membuat pesan yang bersifat pribadi sesuai karakteristik mitra komunikasi; dan kemampuan media untuk menyapaikan isyarat yang beragam (multiple cues).

Sejauh ini admin media sosial Unit Teknologi Informasi dan Inovasi Politeknik Kelautan dan Perikaan Pangandaran dalam mengelola umpan balik yang diterima dari publik adalah dengan selalu menjadi admin media sosial yang cepat tanggap atas suatu permasalahan yang dialami oleh publik berkaitan dengan adanya informasi yang disebarluaskan oleh Politeknik Kelautan dan Perikanan Pangandaran. Admin media sosial selalu berusaha memberikan penjelasan secara mendetail atas semua respon yang diberikan oleh publik baik respon yang sifatnya positif ataupun negatif. Hal tersebut dilakukan dengan tujuan agar publik mendapatkan yang sebenarnya mereka butuhkan dengan baik dan detail.

Melalui penggunaan media sosial oleh Politeknik Kelautan dan Perikanan Pangandaran dapat sekaligus memperkenalkan kementeriannya (Kementerian Kelautan Periakanan) kepada publik luas, hal ini ditujukan sebagai wujud pengenalan dan juga memberikan kesadaran kepada publik akan keeksistensian dari sebuah kementerian dibawah pemerintahan Indonesia yakni Kementerian Kelautan Perikanan Republik Indonesia yang memiliki tugas dan wewenang untuk mengatur seluruh kegiatan kehidupan KKP dan Badan Riset Sumder Daya Manusia Kelautan Perikanan (BRSDM-KP) yang ada diseluruh wilayah di Indonesia.

\section{KESIMPULAN}

Unit Teknologi Informasi dan Inovasi Politeknik Kelautan dan Perikanan Pangandaran dalam upaya penyebarluasan informasi yang dimiliki menggunakan beragam media sosial, antara lain: facebook, twitter, instagram, dan juga youtube. Sejauh ini, penggunaan media sosial oleh Unit Teknologi Informasi dan Inovasi menjadi penting karena melihat ketertarikan dari publik atas informasi yang disebarluaskan melalui media sosial. Dari keempat media sosial yang digunakan oleh Unit Teknologi Informasi dan Inovasi Politeknik Kelautan dan Perikanan Pangandara, satu di antaranya masih dalam proses pengembangan pengelolaan. Media sosial yang dimaksud adalah youtube. Penggunaan youtube masih minim karena untuk mengelola jejaring sosial ini diperlukan persiapan yang cukup matang. Akan tetapi nantinya, penggunaan youtube akan dioptimalkan untuk pengembangan wadah penyebarluasan informasi oleh Unit Teknologi Informasi dan Inovasi Politeknik Kelautan dan Perikanan Pangandaran.

Di lain sisi, penggunaan media sosial sebagai wadah penyebarluasan informasi juga menjadi wadah untuk mendapatkan respon yang bersifat dua arah, maksudnya baik penyebar informasi atau pihak yang mendapatkan informasi tersebut mampu melakukan sebuah hubungan komunikasi melalui kolom komentar yang tersedia dalam media sosial tersebut. Lebih jauh, penggunaan media sosial dalam menyebarkan informasi memiliki respon yang beragam.

Politeknik Kelautan dan Perikanan Pangandaran melalui Unit Teknologi Informasi dan Inovasi mengelola media sosial dengan respon yang diterima dengan sangat baik, mereka melakukan pendekatan responsif dengan selalu menjadi pendengar dan juga pemberi jawaban pasti yang sangat detail sehingga mengurangi kesalahpahaman yang timbul.

Media sosial yang digunakan oleh Politeknik Kelautan dan Perikanan Pangandaran juga menjadi sebuah wadah yang tidak hanya untuk penyebarluasan informasi saja, melainkan juga digunakan sebagai wadah pengenalan Kementerian kepada publik.

Peranan humas Dalam Membangun Eksistensi Politeknik Kelautan dan Perikanan, saat ini sudah mendapat pengakuan keberadaannya oleh semua kalangan. Itu semua dengan pemanfaatan media sosial dalam upaya penyebarluasan informasi yang dilakukan di Politeknik Kelautan dan Perikanan Pangandaran. Unit Teknologi informasi dan Inovasi sebagai admin Media sosial Politeknik Kelautan dan Perikanan Pangandaran selalu berupaya membuat inovasi, kreasi yang kekinian guna menarik minat pengunjung dan pengikut pada akun media sosial yang dimiliki. Selain dengan misi "one day one news" namun dengan membuat tampilan pada media sosial untuk lebih menarik dan kekinian. 


\section{UCAPAN TERIMA KASIH}

Penulis mengucapkan terima kasih kepada segenap Unit Teknologi Informasi dan Inovasi, Bapak DH. Guntur Prabowo A.Pi., M.M Selaku Direktur Politeknik Kelautan dan Perikanan Pangandaran, Bapak Arif Baswantara, S.I.K., M.Si Selaku Ketua Unit Teknologi Informasi dan Inovasi, Bapak Deden Yusman Maulid, S.Pi., M.Si Selaku Ketua Unit Pusat Penelitian Dan Pengambdian Kepada Masyarakat (PPM), Pupu selaku Staf Unit Teknologi Informasi dan Inovasi yang mengelola media sosial atas bantuannya kemudahan dalam mengumpulkan data dalam melakukan penulisan ini.

\section{DAFTAR PUSTAKA}

Afkarina, Izza Nur. (2018). Strategi Komunikasi Humas Dalam Membentuk Public Opinion Lembaga Pendidikan. http:// journal.uinalauddin.ac.id/index.php/idaarah/article/ view/5124/

Azeem, Ribhul Mohammad.(2018). Strategi Humas Kementerian Koperasi dan Usaha Kecil
danMenengah Dalam Pengelolaan Jejaring Sosia. https://journal.untar.ac.id/index.php/ komunikasi/ article/view/2562/1699

Kasmiru, Wiji.(2013). Peran Kehumasan Dalam Membangun Citra Pemerintah di Kabupaten Kutai Barat. http://e-journals.unmul.ac.id/index.php/ JAR/article/view/458report-2016/.

Romalina, Hikmah.. (2011) Peran Petugas Humas. https://sumsel.kemenag.go.id/files/sumsel/file/file/ 1TULISAN/artikel_kehumasan.pdf

Ruslan, Rosady. (2016). Manajemen Public Relations \& Media Komunikasi, Konsepsi, dan Aplikasi. Jakarta : PT. Raja Grafindo Persada.

Seitel, Fraser P. (2001). The Practice of Public Relations, $8^{\text {th }}$ ed. New Jersey: Prentice Hall.

Stelzner, M.A. (2016). Social Media Marketing Industry Report : How To Marketers Are Using Social Media To Grow Their Businesses. http:// www.socialmediaexaminer.com/social-mediamarketing-industry- 